\title{
Warming enhances lanthanum accumulation and toxicity promoting cellular damage in glass eels (Anguilla anguilla)
}

\author{
Cátia Figueiredo $^{\text {a,b,c, }, 1}$, Joana Raimundo ${ }^{\mathrm{a}, \mathrm{d}, 1}$, Ana Rita Lopes ${ }^{\mathrm{a}, \mathrm{e}}$, Clara Lopes ${ }^{\mathrm{b}, \mathrm{d}}$, Nuno Rosa ${ }^{\mathrm{b}}$, \\ Pedro Brito ${ }^{\mathrm{b}}$, Mário Diniz ${ }^{\mathrm{c}}$, Miguel Caetano ${ }^{\mathrm{b}}$, ${ }^{\text {, Tiago F. Grilo }}{ }^{\mathrm{a}}$ \\ ${ }^{a}$ MARE - Marine and Environmental Sciences Centre, Faculdade de Ciências da Universidade de Lisboa, Campo Grande, 1749-016, Lisboa, Portugal \\ b Division of Oceanography and Marine Environment, IPMA - Portuguese Institute for Sea and Atmosphere, Av. Alfredo Magalhães Ramalho, 6, 1495-165, Algés, \\ Portugal \\ ${ }^{\mathrm{c}}$ UCIBIO, REQUIMTE, Departamento de Química, Faculdade de Ciências e Tecnologia, Universidade NOVA de Lisboa, 2829-516, Caparica, Portugal \\ ${ }^{\mathrm{d}}$ CIIMAR, Interdisciplinary Centre of Marine and Environmental Research, Avenida General Norton de Matos S/N, 4450-208, Matosinhos, Portugal \\ ${ }^{\mathrm{e}}$ MARE - Marine and Environmental Science Centre, ISPA - Instituto Universitário, R. Jardim Do Tabaco 34, 1100-304, Lisboa, Portugal
}

\section{A R T I C L E I N F O}

\section{Keywords:}

Warming

Lanthanum

Glass eels

Cellular damage

Heat shock proteins

\begin{abstract}
A B S T R A C T
Cumulative and continuing human emissions of greenhouse gases to the atmosphere are causing ocean warming. Rising temperature is a major threat to aquatic organisms and may affect physiological responses, such as acidbase balance, often compromising species fitness and survival. It is also expected that warming may influence the availability and toxicological effects of pollutants, including Rare Earth Elements. These are contaminants of environmental emerging concern with great economic interest. This group comprises yttrium, scandium and lanthanides, being Lanthanum (La) one of the most common. The European eel (Anguilla anguilla) is critically endangered and constitutes a delicacy in South East Asia and Europe, being subject to an increasing demand on a global scale. Considering the vulnerability of early life stages to contaminants, we exposed glass eels to $1.5 \mu \mathrm{g} \mathrm{L}$ of La for five days, plus five days of depuration, under a present-day temperature and warming $\operatorname{scenarios}(\triangle \mathrm{T}=$ $+4{ }^{\circ} \mathrm{C}$ ). The aim of this study was to assess the bioaccumulation, elimination and specific biochemical enzymatic endpoints in glass eels (Anguilla anguilla) tissues, under warming and La. Overall, our results showed that the accumulation and toxicity of La were enhanced with increasing temperature. The accumulation was higher in the viscera, followed by the head, and ultimately the body. Elimination was less effective under warming. Exposure to La did not impact acetylcholinesterase activity. Moreover, lipid peroxidation peaked after five days under the combined exposure of $\mathrm{La}$ and warming. The expression of heat shock proteins was majorly suppressed in glass eels exposed to La, at both tested temperatures. This result suggests that, when exposed to La, glass eels were unable to efficiently prevent cellular damage, with a particularly dramatic setup in a near-future scenario. Further studies are needed towards a better understanding of the effects of lanthanum in a changing world.
\end{abstract}

\section{Introduction}

The latest reports of the Intergovernmental Panel on Climate Change (IPCC) have been focusing on rising greenhouse gas emissions derived from human activities that are causing global warming (Aljerf, 2016). According to the IPCC's high greenhouse gas emission scenario (RCP8.5) the global mean surface air temperature may rise up to $4.9^{\circ} \mathrm{C}$ for the period 2081-2100, relative to the recent past (1986-2005) reference period (IPCC et al., 2019). In parallel, key ocean variables are experiencing profound changes associated with absorption of greenhouse gases by the ocean, manifested through alterations in temperature, $\mathrm{pH}$, dissolved oxygen, among others (Doney et al., 2011; IPCC et al., 2019). In fact, warming is one of the biggest stressors to aquatic organisms, having the potential to disturb physiological responses, such as acid-base balance, which in turn can compromise species fitness and survival (Pankhurst and Munday, 2011; Pörtner and Peck, 2010). Under hostile environments (e.g. thermal stress), to cope with physiological stress and avoid cellular damage (Lushchak, 2011), aquatic organisms

\footnotetext{
* Corresponding author. MARE - Marine and Environmental Sciences Centre, Faculdade de Ciências da Universidade de Lisboa, Campo Grande, 1749-016, Lisboa, Portugal.

E-mail address: cafigueiredo@fc.ul.pt (C. Figueiredo).

1 Authors equally contributed to the work.
} 
hold protective mechanisms and antioxidant defenses to counteract the overproduction of reactive oxygen species (ROS). Among the most frequent physiological strategies are protein repair and removal mechanisms, including the synthesis of heat shock proteins (HSPs) (Sørensen et al., 2003), which activity is temperature-dependent (Alexandrov, 1969). Another mechanism is lipid peroxidation (LPO) which occurs when ROS react with lipids (Sachdeva et al., 2014). Warming can also interfere with acetylcholinesterase (AChE) activity, being able to modify the levels of the neurotransmitter acetylcholine (Halliwell and Gutteridge, 2015), that mediates nervous communication and ensures the optimal neuronal function. In addition, organisms proteome is responsible for genome repair, replication and expression, however it is expected that environmental stressors impact, to a certain degree, the DNA structure, causing DNA damage (Gueranger et al., 2014; Krisko et al., 2013). Reactive oxygen species can attack either DNA bases or the deoxyribose backbone, resulting, for example, in the oxidation of guanine in the $\mathrm{C} 8$ position that culminates in the easy formation of amongst studied DNA lesions suspected of mutagenicity - 8-hydrox$\mathrm{y}-2^{\prime}$-deoxyguanosine (8-OHdG). When $8-\mathrm{OHdG}$ residues are present in DNA, GC to TA transversion occurs unless repaired prior to DNA replication (Cheng et al., 1992). 8-OHdG is an easier repairable genetic alteration than irreversible chromosomal damage and has been used as a biomarker of environmental contamination, particularly in fish from polluted sites (Oliveira et al., 2010).

Besides temperature, an additional pressure that aquatic organisms are also dealing is contamination, manifested by the release of anthropogenic pollutants into the ocean as a consequence of increasing industrialization, technological progress and urbanization (Bukola et al., 2015). The great concern about contamination of aquatic ecosystems is reliant on potential interactions that may occur with other stressors, including temperature, since the availability and toxicological effects of pollutants may be altered by warming (Marques et al., 2010). Specifically, contaminants of environmental emerging concern have gathered the attention of the scientific community and regulatory authorities, since the risks they may pose to human health and biota are still poorly understood (Herrmann et al., 2016; Pagano et al., 2015). As examples of these contaminants are the Rare Earth Elements (REEs), in which are included the lanthanides, yttrium and scandium. Their use is key for numerous areas such as electronic technology, medical and industrial products, agriculture and aquaculture, as bactericides or fertilizers (Wall, 2014). The increasing application of REEs in these technologies and industries culminates in their transfer to aquatic ecosystems by means of both wastewater and industrial emission (Kulaksiz and Bau, 2011). Furthermore, an ever-growing modern world demands state-of-the-art modern electronic devices of daily use, such as smartphones, screens and tablets. The constant demand for newer and updated modern versions of these equipments has led to shorter lifespans which in turn is fasting the production of alarming quantities of electronic waste (e-waste) (Needhidasan et al., 2014). The dismantling, storage and burning of this e-waste may also represent REEs contamination for the aquatic environment (Sepúlveda et al., 2010; Uchida et al., 2018). The urgent need for a better understanding of their impacts is evident when looking to the reviews available on the toxicity of REEs (e.g. Herrmann et al., 2016 and references herein).

Lanthanum (La) is the second most common REEs (Herrmann et al., 2016) and is mostly present in the stable oxidation state +3 , and due to their comparable ionic radius, it is known to compete with the ion $\mathrm{Ca}^{2+}$ in organisms. (Qinhai, 1996; Zepf, 2013). This element is commonly used in many industrial applications (e.g. Rattanaphra et al., 2019), however very few studies exist on the toxicological effects of La in aquatic systems (e.g. Cui et al., 2012; Moreira et al., 2020; Pinto et al., 2019), including a previous one dealing with juvenile stages of the European eel (Anguilla anguilla) (Figueiredo et al., 2018).

The natural populations of the European eel are critically endangered, according to the International Union for the Conservation of Nature, facing severe risk of extinction. A wide range of anthropogenic pressures are causative of the downfall of juvenile eel recruitment, such as overexploitation of this food resource, increasing contamination of its habitat and indirectly habitat loss, cumulative alien parasitoid species and climate change (Drouineau et al., 2018). The European eel has remarkable ecological features, typical of a catadromous species, comprising both oceanic and continental life phases, thus establishing the link between the open sea and inland rivers and lakes. Adult eels migrate from inland rivers to the Sargasso Sea to reproduce and die. The newborn leptocephali larvae migrate for up two years to reach the European coast. The larvae metamorphose then into glass eels and continue their journey through estuaries and upriver (Lecomte-Finiger, 1994). Glass eels are a delicacy in South East Asia and Europe (Crook and Nakamura, 2013), and their market price may reach thousands euros, being therefore a lucrative resource subject to an increasing demand and illegal trafficking.

Fish early life stages have been recognized as more susceptible to climate change and pollutants than adult forms, which makes this juvenile eel stage even a more interesting model for experimentation, as demonstrated previously with lanthanum and mercury (e.g. Figueiredo et al., 2018; Grilo et al., 2015). Accordingly, the chief purpose of the present study was to assess the bioaccumulation and elimination of lanthanum-exposed glass eels tissues under present-day temperatures and warming $\left(\triangle \mathrm{T}=+4{ }^{\circ} \mathrm{C}\right)$ scenarios. In order to complement and understand better the physiological responses derived from La accumulation in eel tissues, specific biomarkers, indicative of cellular damage, will also be determined.

\section{Material and methods}

\subsection{Sampling site}

Specimens were captured using hand-held dip nets and stow nets of 0.5-1,0 mm mesh size, in October 2018, in the oligohaline section of the Mondego River, on the central Atlantic coast of Portugal (SW Europe), in a sole sampling occasion. Glass eels were immediately transferred to MARE-FCUL aquaculture facilities and maintained in tanks with continuously aerated water from the sample location, as in accordance with Grilo et al. (2015).

\subsection{Experimental design}

Three hundred and twenty glass eels were randomly distributed in tanks with continuously aerated dechlorinated tap water filtered through a $0.45-\mu \mathrm{m}$ pore size membrane filter. Acclimation under a $12 \mathrm{~h}$ light $/ 2 \mathrm{~h}$ dark photoperiod and salinity $=0$ (V2 refractometer, TMC Iberia, Portugal), water temperature $=18{ }^{\circ} \mathrm{C} \pm 0.5^{\circ} \mathrm{C}$ (TFX 430 Precision Thermometer, WTW GmbH, Germany) and $\mathrm{pH}=7.9 \pm 0.1$ (SG8 e SevenGo pro $^{\mathrm{TM}} \mathrm{pH} / \mathrm{Ion}$ meter, Mettler-Toledo International Inc., Switzerland), representing the natural habitat, lasted two weeks. Glass eels were measured $(6.6 \pm 0.7 \mathrm{~cm})$ and weighted $(0.17 \pm 0.02 \mathrm{~g}$, wet weight). In tanks mimicking the warming treatments, the water temperature was raised $1{ }^{\circ} \mathrm{C}$ a day, to gradually allow acclimation before the start of the experiment. After the acclimation, the trial began with the following treatments: i) Control temperature $\left(18{ }^{\circ} \mathrm{C}\right.$, added $\mathrm{La}=0 \mu \mathrm{g}$ $\left.\mathrm{L}^{-1}\right)$; ii) exposed at the control temperature $\left(18{ }^{\circ} \mathrm{C}\right.$, added $\mathrm{La}=1.5 \mu \mathrm{g}$ $\left.\mathrm{L}^{-1}\right)$; iii) warming $\left(22^{\circ} \mathrm{C}\right.$, added $\left.\mathrm{La}=0 \mu \mathrm{g} \mathrm{L}{ }^{-1}\right)$ and iv) exposed at the warming temperature $\left(22{ }^{\circ} \mathrm{C}\right.$, added $\left.\mathrm{La}=1.5 \mu \mathrm{g} \mathrm{L}^{-1}\right)$. Throughout the experiment, a pH value of $7.9 \pm 0.1$ and a total water hardness of $105 \pm$ $5 \mathrm{mg} \mathrm{L}^{-1} \mathrm{CaCO}_{3}$ (moderately hard) were registered. Water temperature was controlled through submerged heaters $\left(\mathrm{V}_{2}\right.$ Therm $200 \mathrm{~W}$ aquarium heater, TMC Iberia, Portugal), and through seawater chillers (Hailea, HC-250 A, Guangdong, China) in a water bath containing the experimental tanks. A La solution ( $\mathrm{LaCl}_{3}$, Merck), prepared in filtered freshwater, was added daily in the exposed treatments to warrant the La exposure. The water of the experimental tanks was completely renewed daily, at the same time, for the four treatments and the La concentration 
re-established with $1.5 \mu \mathrm{g} \mathrm{L}^{-1}$, in the exposed treatments. The selected concentration is representative of levels present in polluted aquatic environments (e.g. Aström, 2001) and is comparable to other ecotoxicology trials (e.g. Moreira et al., 2020; Pinto et al., 2019). Water aliquots were sampled after $1 \mathrm{~h}, 3 \mathrm{~h}, 6 \mathrm{~h}, 12 \mathrm{~h}$ and $24 \mathrm{~h}$ of the first exposure to measure dissolved La levels. One hour before the water renewal, individuals were fed ad libitum cod roe, every other day. Glass eels were sampled after 1 (T1), 3 (T3) and 5 (T5) days of exposure to La. Following this exposure phase, the freshwater was renewed and the elimination phase began, which lasted for 5 more days (T10). During this the water was also completely renewed daily at the same time, for all treatments, and animals kept being fed ad libitum every other day.

For the La quantification individuals were separated into three body parts: head, viscera (comprising the internal organs) and skinless body (the skin layer was removed). For the biomarkers' quantification individuals were separated into two body parts: head and remaining body (containing the internal organs and without the skin layer).

Samples were stored at $-80{ }^{\circ} \mathrm{C}$ until further analyses.

\subsection{Lanthanum quantification}

Dissolved La concentrations $\left(\mu \mathrm{g} \mathrm{L}^{-1}\right.$ ) were analyzed in filtrated and acidified ( $2 \%$ ultrapur $\mathrm{HNO}_{3}$ ) water samples. In glass eels' tissues, La was determined in freeze-dried, grounded and homogenized samples (n $=10$ per treatment), after digestion with $\mathrm{HNO}_{3}$ (destilled, $65 \% \mathrm{v} / \mathrm{v}$ ) and $\mathrm{H}_{2} \mathrm{O}_{2}$ (suprapur, $30 \% \mathrm{v} / \mathrm{v}$ ). Before digestions, labware was decontaminated with $\mathrm{HNO}_{3}(20 \%)$ for two days and rinsed with ultra-pure water (Milli-Q water - 18.2 M $\Omega$ ). A quadrupole ICP-MS (Thermo Elemental, XSeries) with a Peltier impact bead spray chamber and a concentric Meinhard nebulizer was used to determine La concentrations, following the experimental condition described in Raimundo et al. (2013).

La concentrations in glass eels body parts are presented in nanogram per gram of tissue dry weight $\left(\mathrm{ng} \mathrm{g}^{-1}, \mathrm{dw}\right)$.

\subsubsection{Quality assurance and control}

A nine-point calibration curve was used to quantify La, using a commercial solution of indium (In) as an internal standard (Merck, CertiPUR $($ ). Three procedural blanks, prepared using the analytical procedure, and a quality control solution, used to evaluate the accuracy of the determinations, were included within each batch of 20 samples. Blanks accounted for less than $1 \%$ of the total La concentration in the samples.

The international certified reference material BCR 668 (muscle of Mytilus edulis), was also included within each batch of 20 samples to assess the accuracy of the analytic method.

\subsection{Biomarkers}

The heads and the remaining bodies ( $\mathrm{n}=10$ per treatment) of randomly collected individuals were homogenized (Ultra-Turrax, Staufen, Germany) in $0.5 \mathrm{~mL}$ of phosphate buffered saline solution (PBS: 2.7 $\mathrm{mM} \mathrm{KCl}, 0.14 \mathrm{M} \mathrm{NaCl}, 1.47 \mathrm{mM} \mathrm{KH}_{2} \mathrm{PO}_{4}, 8.1 \mathrm{mM} \mathrm{Na}_{2} \mathrm{HPO}_{4}$ and, $\mathrm{pH}$ 7.4). Homogenates were centrifuged at $10.000 \times g$ for $15 \mathrm{~min}$ at $4{ }^{\circ} \mathrm{C}$ and then supernatants were frozen $\left(-80^{\circ} \mathrm{C}\right)$ until further analyses. Each sample was run in technical replicates (triplicates), and the enzyme results were normalized to total protein content, as in Bradford (1976).

\subsubsection{Neurotoxicity marker - Acetylcholinesterase}

Acetylcholinesterase (AChE) activity was determined in the head of the glass eels according to an adaptation of the Ellman et al. (1961) method to 96-well microplates, as described by Figueiredo et al. (2018). For each sample, $25 \mu \mathrm{L}$ of sample and $250 \mu \mathrm{L}$ of a mix solution $(50 \mathrm{mM}$ of sodium phosphate, $75 \mathrm{mM}$ acetylthiocholine iodide and $1 \mathrm{mM}$ of 5 , 5'-dithio-bis-2-nitrobenzoic acid) were added to a 96-well microplate (Greiner Bio-one, Austria). The absorbance was read in a microplate reader at $415 \mathrm{~nm}$ (Biotek Synergy HTX multimode reader) every minute for $10 \mathrm{~min}$. Acetylcholinesterase measurements were standardized to total protein concentration ( $\mathrm{nmol} \mathrm{min}^{-1} \mathrm{mg}^{-1}$ total protein).

\subsubsection{Oxidative damage markers - DNA damage and lipid peroxidation}

DNA damage was measured in the head and remaining body of the glass eels, with an ELISA method and through quantification of 8-hydroxy-2'-deoxyguanosine (8-OHdG), as described in Lopes et al. (2019). This compound has been widely chosen as a biomarker of environmental contamination linked with DNA damage and its presence in cells may lead to mutagenesis and thus play a significant role in disease processes (Cooke et al., 2003; Oliveira et al., 2010). For our analysis, a total of 100 $\mu \mathrm{L}$ of each sample was added to 96-well microplates (Greiner Bio-one, Austria) and allowed to incubate overnight at $4{ }^{\circ} \mathrm{C}$. The plates were then washed three times with PBS-TWEEN 20, and incubated for $90 \mathrm{~min}$ at room temperature with $200 \mu \mathrm{L}$ of $1 \%$ bovine serum albumin (BSA, NZYTech, 985, Portugal). After another washing procedure, microplates were incubated overnight with the primary antibody (anti-OHdG, clone 15 A3, Sigma-Aldrich, Germany). Microplates were again washed, and incubated for $90 \mathrm{~min}$ at $37{ }^{\circ} \mathrm{C}$ with the secondary antibody (alkaline phosphatase-conjugated anti-mouse IgG, Fab specific, Sigma-Aldrich, USA). After a final washing procedure, plates were incubated for 30 min at room temperature with the substrate (SIGMA FASTTM p-Nitrophenyl Phosphate Tablets, Sigma-Aldrich, USA). The reaction was stopped, after $30 \mathrm{~min}$, through the addition of $100 \mu \mathrm{L}$ of $3 \mathrm{M} \mathrm{NaOH}$. The absorbance was read at $405 \mathrm{~nm}$ using a microplate reader (Biotek Synergy HTX multi-mode reader).

Lipid peroxidation (LPO) was determined in glass eels' remaining body according to the thiobarbituric acid reactive substances (TBARS) assay (Uchiyama and Mihara, 1978), over the quantification of malondialdehyde (MDA), an end product of lipid damage.

Five $\mu \mathrm{L}$ of each sample, $45 \mu \mathrm{L}$ of monobasic sodium phosphate buffer (50 mM), $12.5 \mu \mathrm{L}$ of sodium dodecyl sulfate $(8.1 \%)$, $93.5 \mu \mathrm{L}$ of trichloroacetic acid (20\%, pH 3.5), $93.5 \mu \mathrm{L}$ of thiobarbituric acid (1\%), and $50.5 \mu \mathrm{L}$ of Milli-Q ultrapure water were added to a microtube. Subsequently microtubes were placed in boiling water $\left(100^{\circ} \mathrm{C}\right)$ for $10 \mathrm{~min}$. Then, microtubes were placed on ice until cool and $62.5 \mu \mathrm{L}$ of Milli-Q ultrapure water was added. Finally, $150 \mu \mathrm{L}$ of each sample was added to 96-well microplates (Greiner Bio-one, Austria), and the absorbance read at $532 \mathrm{~nm}$ (Biotek Synergy HTX multi-mode reader). Malondialdehyde (MDA) concentrations were calculated based on a calibration curve (0-0.3 $\mu \mathrm{M}$ MDA).

\subsubsection{Heat shock proteins}

Heat Shock Protein 70 (HSP) were quantified in the supernatants of the homogenate and centrifuged glass eels' remaining body through ELISA, as described in Lopes et al. (2018). In sum, $10 \mu \mathrm{L}$ of sample diluted in $980 \mu \mathrm{L}$ PBS was added to 96-well microplate (Microlon 600, Greiner, Austria) and allowed to incubate overnight at $4{ }^{\circ} \mathrm{C}$. On the next day, microplates were washed three times with PBS TWEEN-20 (0.05\%). Later, $100 \mu \mathrm{L}$ of BSA (1\% bovine serum albumin, NZYtech, 98\%, Portugal) was added to each well, and microplates incubated for $90 \mathrm{~min}$ at $37{ }^{\circ} \mathrm{C}$. Then, $50 \mu \mathrm{L}$ of primary antibody $5 \mu \mathrm{g} \mathrm{mL}^{-1}$ of anti-HSP70/HSC70 in 1\% BSA (Acris, USA) was added to each well. Microplates were once more incubated overnight at $4{ }^{\circ} \mathrm{C}$. After being washed three times, microplates were allowed to incubate for $90 \mathrm{~min}$ at $37{ }^{\circ} \mathrm{C}$ with the second antibody [50 $\mu \mathrm{L}$ of $1 \mu \mathrm{g} \mathrm{mL}-1$; alkaline phosphatase-conjugated anti-mouse IgG (Fab specific, Sigma-Aldrich, USA)]. After the last washing procedure, $100 \mu \mathrm{L}$ of the substrate (SIGMA FASTTM p-Nitrophenyl Phosphate Tablets, Sigma-Aldrich, USA) was added to each well and incubated for $30 \mathrm{~min}$ at room temperature. Finally, $50 \mu \mathrm{L}$ of stop solution $(3 \mathrm{M} \mathrm{NaOH})$ was added to each well and the absorbances read at $405 \mathrm{~nm}$ (Biotek Synergy HTX multi-mode reader). HSP content was calculated from the calibration curve, based on serial dilutions of purified HSP70 active protein (0-2.000 $\mu \mathrm{g} \mathrm{mL}^{-1}$, OriGene Technology, USA) and data normalized to sample protein ( $\mu \mathrm{g} \mathrm{mg}^{-1}$ total protein). 


\subsection{Statistical analyses}

Normality and equality of variances were tested with KolmogorovSmirnov and Levene's tests, respectively. Differences between the four treatments within each sampling time, for lanthanum accumulation and elimination, AChE activity, DNA damage, LPO (MDA levels) and HSP were tested via ANOVA followed by Tukey HSD post hoc tests. These analyses were performed in STATISTICA ${ }^{\mathrm{TM}} 12$ software (Statsoft, Inc., Tulsa, OK 74104, USA). A significance level of $p<0.05$ was applied.

\section{Results}

Median La levels ( $\mu \mathrm{g} \mathrm{L}^{-1}$ ) in the water aliquots sampled after 1, 3, 6, 12 and $24 \mathrm{~h}$ of exposure are presented in Supplemental Table 1. Median concentrations in the first $24 \mathrm{~h}$ were $0.034 \mu \mathrm{g} \mathrm{L}{ }^{-1}$ in the $18^{\circ} \mathrm{C}$ and 0.057 $\mu \mathrm{g} \mathrm{L}^{-1}$ in the $22{ }^{\circ} \mathrm{C}$ non-spiked tanks. In the spiked tanks, dissolved median La concentrations were 1.3 and $1.6 \mu \mathrm{g} \mathrm{L}-1$ in the $18{ }^{\circ} \mathrm{C}$ and $22{ }^{\circ} \mathrm{C}$ tanks, respectively. Concentrations in spiked tanks varied $6-13 \%$ from the nominal concentrations $\left(1.5 \mu \mathrm{g} \mathrm{L}^{-1}\right)$.

\subsection{Bioaccumulation and elimination}

Median and ranges of La concentrations (ng $\mathrm{g}^{-1}$, dry weight) in the head, skinless body and viscera are presented in Table 1 .

\subsubsection{Head}

Concentrations of La (ng $\mathrm{g}^{-1}$, dry weight) in the glass eels' heads are presented in Fig. 1.

After one day of exposure (T1) no significant differences were observed between the four treatments, yet after three days of exposure (T3) a significant accumulation occurred in the warming treatment ( $p=$ 0.026). This significant difference from their corresponding control was higher after 5 days of exposure ( $5, p=0.004)$. Interestingly, the exposed treatment at $18{ }^{\circ} \mathrm{C}$, although higher was never statistically different from their control counterpart, even though there was a trend for La to be accumulated at this temperature. A decrease in La concentration during the elimination phase was observed, nevertheless the post-exposed eels in warming treatment did not reach lanthanum

\section{Table 1}

Median and ranges of La concentration (ng $\mathrm{g}^{-1}$, dry weight) of the control, exposed and post-exposed glass eels' head, skinless body and viscera at T1, T3, $\mathrm{T} 5$ and $\mathrm{T} 10$, at $18{ }^{\circ} \mathrm{C}$ and $22^{\circ} \mathrm{C}$. Asterisk indicate the presence of concentrations below detection limit value $\left(1.4 \mathrm{ng} \mathrm{g}^{-1}, \mathrm{dw}\right)$.

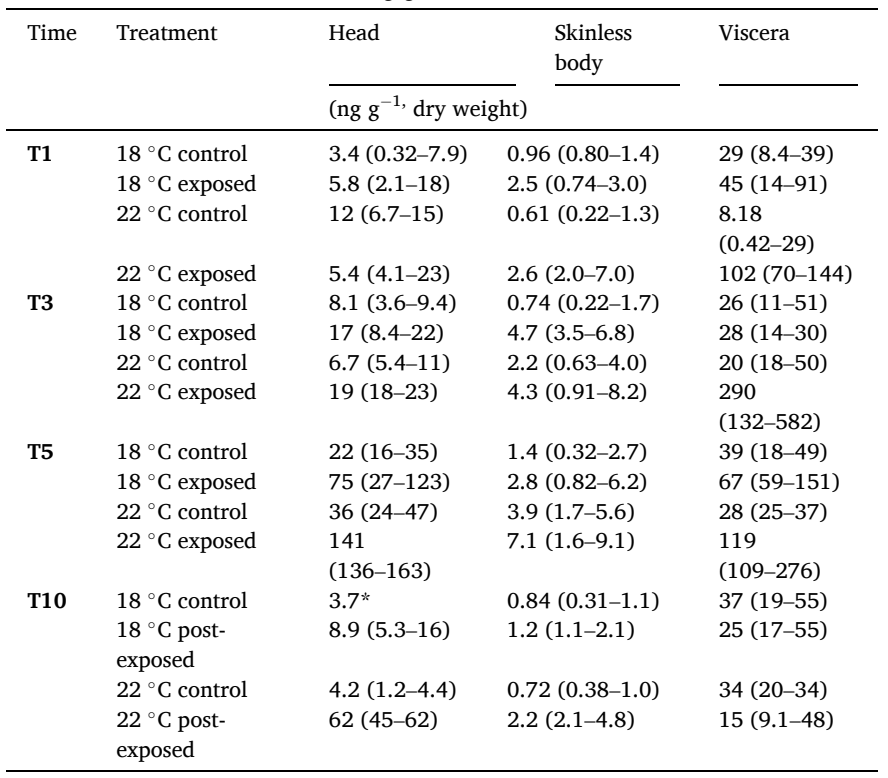

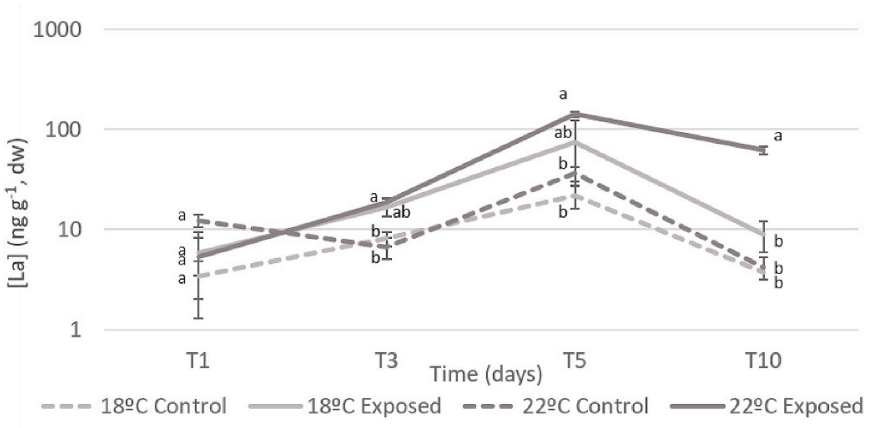

Fig. 1. Concentrations of lanthanum (ng $\mathrm{g}^{-1}$, dry weight) of the control, La exposed and post-exposed glass eels' head at $18{ }^{\circ} \mathrm{C}$ and $22{ }^{\circ} \mathrm{C}$ in the different sampling times (T1, T3, T5 and T10). Values represent medians \pm SE. Different letters represent significant differences between treatments within each sampling time ( $\mathrm{p}<0.05)$.

concentrations similar to the control values $(p=0.022)$.

\subsubsection{Skinless body}

At $22{ }^{\circ} \mathrm{C}$ there was a constant increase in the concentration of La in the exposed glass eels' body (Fig. 2), for the 5 exposure days, although a statistically significant difference between the exposed and the control was only observed in T1 $(p=0.007)$. This concentration decreased during elimination (T10), however not reaching control values ( $p=$ $0.003)$. At $18^{\circ} \mathrm{C}$, accumulation peaked at $\mathrm{T} 3(p=0.02)$. Interestingly, La concentration decreased from T3 onwards, in glass eels exposed at $18^{\circ} \mathrm{C}$, even in a continuously contaminated environment.

\subsubsection{Viscera}

Concentrations of $\mathrm{La}_{\text {(ng g }}{ }^{-1}$, dry weight) in the glass eels' viscera are presented in Fig. 3.

Accumulation in the exposed eels at the warming treatment was greater than in the exposed eels at $18{ }^{\circ} \mathrm{C}$, except in T5. During the exposure phase, at the warming scenario, accumulation in the viscera occurred in the three sampling periods $(p=0.0001, p=0.0005, p=$ 0.004 , respectively). There was no statistical difference between the exposed eels at $18{ }^{\circ} \mathrm{C}$ and their control counterpart $(p>0.05)$ over time. Lanthanum concentrations in exposed eels' viscera decreased, at both temperatures, during the post-exposure period to values comparable to the controls $(p>0.05)$.

\subsection{Biomarkers}

Median and ranges of acetylcholinesterase activity (AChE, nmol

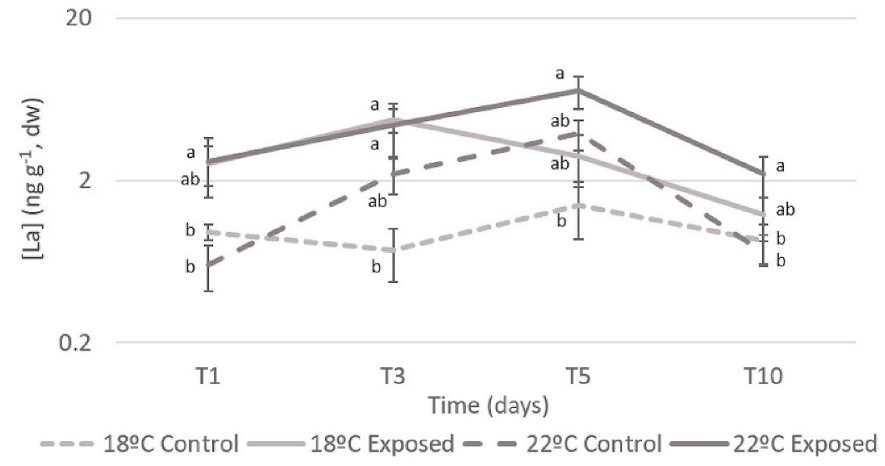

Fig. 2. Concentrations of lanthanum (ng g ${ }^{-1}$, dry weight) of the control, La exposed and post-exposed glass eels' skinless body at $18{ }^{\circ} \mathrm{C}$ and $22{ }^{\circ} \mathrm{C}$ in the different sampling times (T1, T3, T5 and T10). Values represent medians $\pm \mathrm{SE}$. Different letters represent significant differences between treatments within each sampling time $(\mathrm{p}<0.05)$. 


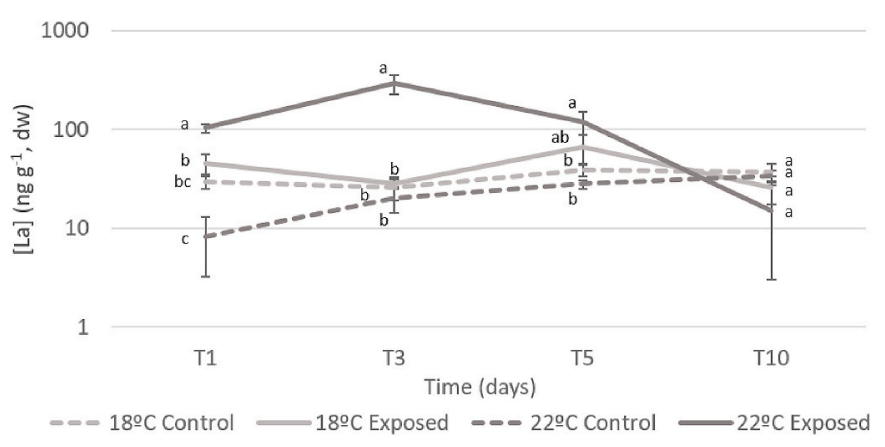

Fig. 3. Concentrations of lanthanum (ng $\mathrm{g}^{-1}$, dry weight) of the control, La exposed and post-exposed glass eels' viscera at $18{ }^{\circ} \mathrm{C}$ and $22{ }^{\circ} \mathrm{C}$ in the different sampling times (T1, T3, T5 and T10). Values represent medians \pm SE. Different letters represent significant differences between treatments within each sampling time $(\mathrm{p}<0.05)$.

$\mathrm{min}^{-1} \mathrm{mg}^{-1}$ total protein), DNA damage (determined via the quantification of $8-\mathrm{OHdG}$, abs $\mathrm{mg}^{-1}$ protein), lipid peroxidation values (MDA concentrations, $\mathrm{nmol} \mathrm{mg}^{-1}$ total protein) and heat shock protein $70(\mu \mathrm{g}$ $\mathrm{mg}^{-1}$ protein) in the head and body are presented in Table 2 .

\subsubsection{Head}

3.2.1.1. AChE. Median values of AChE activity $\left(\mathrm{nmol} \mathrm{min}{ }^{-1} \mathrm{mg}^{-1}\right.$ total protein) in the head are presented in Fig. 4A.

There were no significant differences between the glass eels exposed to La and those non-exposed, at both temperatures $(p>0.05)$, during both exposure (T1, T3, T5) and elimination phase (T10).

3.2.1.2. DNA damage. DNA damage (determined via the quantification of 8-OHdG, abs $\mathrm{mg}^{-1}$ total protein) occurred in the head of glass eels (Fig. 4B) exposed at $22{ }^{\circ} \mathrm{C}(p=0.035)$, after just one day of exposure (T1), compared to the equivalent non-exposed La treatment at the same temperature. At T5, DNA damage peaked in glass eels' heads exposed at the warming treatment, but not statistically significantly different from their control. After the elimination period (T10), DNA Damage, for both temperatures, did not decrease significantly, still there were differences between glass eels exposed at $22^{\circ} \mathrm{C}$ and their equivalent controls at the same temperature.

\subsubsection{Body}

3.2.2.1. LPO. Malondialdehyde (MDA concentrations, $\mathrm{nmol} \mathrm{mg}^{-1}$ total protein) medians (Fig. 5A) were lower in the exposed glass eels' body than their equivalent controls, for both temperatures $\left(18^{\circ} \mathrm{C}, p=0.005\right.$ and $22{ }^{\circ} \mathrm{C}, p=0.025$ ), after just one day of exposure (T1).

Furthermore, the MDA values increased in the exposed glass eels' body in the warming scenario, reaching the highest values at T5. The exposed eels at $18{ }^{\circ} \mathrm{C}$ did not follow this trend. After the elimination period (T10) the MDA values that had peaked at T5 for La exposed eels in a warming scenario, decreased to values similar to the controls.

3.2.2.2. DNA damage. Median values of DNA damage (determined via the quantification of $8-\mathrm{OHdG}$, abs $\mathrm{mg}^{-1}$ total protein) in the body are presented in Fig. 5B. Lanthanum exposed treatment at $18{ }^{\circ} \mathrm{C}$, at $\mathrm{T} 1$, exhibited lower values than their control counterpart $(p=0.0005)$. However, these values increased significantly, reaching a peak at T5 and being different than their control $(p=0.0002)$. Regarding glass eels exposed to a combined scenario of La and warming, it was only at T5, that values of DNA damage differed, when compared to their control counterparts $(p=0.009)$. At T10 values of both exposed $18{ }^{\circ} \mathrm{C}$ and $22{ }^{\circ} \mathrm{C}$ matched with controls.

3.2.2.3. HSP. At $\mathrm{T} 1 \mathrm{La}$ exposed eels in a warming scenario showed a much lower expression of HSP (Fig. 5C), than their control counterparts $(p=0.004)$ and persisted fairly stable over time. Values of HSP decreased substantially in La exposed glass eels at $18{ }^{\circ} \mathrm{C}$ at T3 and were different from their respective control $(p=0.04)$. By the fifth day of exposure, the control at the warming scenario presented higher expression of HSP, than the control at $18{ }^{\circ} \mathrm{C}(p=0.002)$. The five-day elimination phase was insufficient to restore the expression of HSP, with post-exposed glass eels at both temperatures, presenting lower expressions of HSP than their controls $\left(18^{\circ} \mathrm{C}-p=0.004\right.$ and $22^{\circ} \mathrm{C}-p=$ 0.0007).

\section{Discussion}

The input of contaminants to the environment often results in deleterious effects on wildlife, and ultimately on human health. Warmer temperatures impose additional pressure on wildlife, by changing ecosystems structure (Cheung et al., 2009). Recent research confirmed that warming significantly decreased glass eels' survival (Borges et al., 2019). This reinforces the assumption that the combination of increasing

Table 2

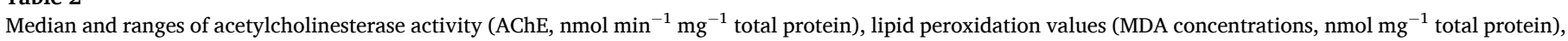

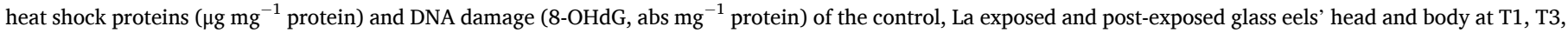
T5 and $\mathrm{T} 10$, at $18{ }^{\circ} \mathrm{C}$ and $22^{\circ} \mathrm{C}$.

\begin{tabular}{|c|c|c|c|c|c|c|c|}
\hline \multirow{3}{*}{ Time } & \multirow{3}{*}{ Treatment } & \multicolumn{3}{|l|}{ Head } & \multicolumn{3}{|l|}{ Body } \\
\hline & & \multicolumn{2}{|l|}{ AChE } & \multirow{2}{*}{$\frac{\text { DNA Damage }}{\text { 8-OHdG (abs/mg protein) }}$} & \multirow{2}{*}{$\frac{\mathrm{LPO}}{\left(\mathrm{nmol} \mathrm{mg}{ }^{-1} \text { total protein }\right)}$} & \multirow{2}{*}{$\frac{\text { DNA Damage }}{\text { 8-OHdG (abs/mg protein) }}$} & \multirow{2}{*}{$\frac{\text { HSP }}{(\mu \mathrm{g} / \mathrm{mg} \text { protein })}$} \\
\hline & & $\left(\mathrm{nmol} \mathrm{min}{ }^{-1} \mathrm{mg}^{-1}\right.$ & total protein) & & & & \\
\hline \multirow[t]{4}{*}{ T1 } & $18^{\circ} \mathrm{C}$ control & $292(197-568)$ & \multicolumn{2}{|c|}{$0.054(0.047-0.069)$} & $0.028(0.06-0.039)$ & $0.058(0.051-0.068)$ & $1054(526-1086)$ \\
\hline & $18^{\circ} \mathrm{C}$ exposed & $237(178-284)$ & \multicolumn{2}{|c|}{$0.072(0.061-0.088)$} & $0.019(0.010-0.025)$ & $0.046(0.042-0.059)$ & 1045 (317-1385) \\
\hline & $22{ }^{\circ} \mathrm{C}$ control & 287 (212-357) & \multicolumn{2}{|c|}{$0.053(0.041-0.065)$} & $0.017(0.012-0.024)$ & $0.052(0.045-0.059)$ & $1121(681-1311)$ \\
\hline & $22{ }^{\circ} \mathrm{C}$ exposed & $168(144-243)$ & \multicolumn{2}{|c|}{$0.064(0.051-0.092)$} & $0.008(0.003-0.015)$ & $0.053(0.050-0.066)$ & $298(235-888)$ \\
\hline \multirow[t]{4}{*}{ T3 } & $18^{\circ} \mathrm{C}$ control & $252(150-286)$ & \multicolumn{2}{|c|}{$0.067(0.060-0.072)$} & $0.022(0.011-0.069)$ & $0.054(0.049-0.059)$ & $821(747-881)$ \\
\hline & $18^{\circ} \mathrm{C}$ exposed & $225(150-352)$ & \multicolumn{2}{|c|}{$0.076(0.058-0.094)$} & $0.013(0.007-0.025)$ & $0.056(0.046-0.068)$ & $446(316-760)$ \\
\hline & $22{ }^{\circ} \mathrm{C}$ control & 218 (194-292) & \multicolumn{2}{|c|}{$0.069(0.065-0.078)$} & $0.018(0.011-0.038)$ & $0.052(0.044-0.064)$ & 1146 (856-1327) \\
\hline & $22{ }^{\circ} \mathrm{C}$ exposed & 263 (214-296) & \multicolumn{2}{|c|}{$0.077(0.072-0.084)$} & $0.018(0.011-0.019)$ & $0.058(0.053-0.069)$ & 357 (253-695) \\
\hline \multirow[t]{4}{*}{ T5 } & $18^{\circ} \mathrm{C}$ control & 231 (168-269) & \multicolumn{2}{|c|}{$0.063(0.054-0.068)$} & $0.028(0.023-0.041)$ & $0.047(0.043-0.052)$ & $820(670-876)$ \\
\hline & $18^{\circ} \mathrm{C}$ exposed & 265 (164-369) & \multicolumn{2}{|c|}{$0.068(0.066-0.099)$} & $0.017(0.016-0.028)$ & $0.067(0.060-0.079)$ & $414(204-508)$ \\
\hline & $22{ }^{\circ} \mathrm{C}$ control & $280(236-327)$ & \multicolumn{2}{|c|}{$0.063(0.063-0.064)$} & $0.020(0.012-0.025)$ & $0.048(0.045-0.054)$ & $1239(1089-1334)$ \\
\hline & $22{ }^{\circ} \mathrm{C}$ exposed & $269(202-321)$ & \multicolumn{2}{|c|}{$0.081(0.073-0.098)$} & $0.049(0.021-0.097)$ & $0.058(0.055-0.063)$ & 313 (201-695) \\
\hline \multirow[t]{4}{*}{ T10 } & $18^{\circ} \mathrm{C}$ control & 234 (159-267) & \multicolumn{2}{|c|}{$0.075(0.066-0.075)$} & $0.035(0.032-0.044)$ & $0.065(0.050-0.077)$ & 943 (730-947) \\
\hline & $18^{\circ} \mathrm{C}$ post-exposed & 227 (200-297) & \multicolumn{2}{|c|}{$0.095(0.094-0.095)$} & $0.025(0.022-0.055)$ & $0.061(0.052-0.066)$ & 317 (264-368) \\
\hline & $22{ }^{\circ} \mathrm{C}$ control & $223(215-236)$ & \multicolumn{2}{|c|}{$0.078(0.072-0.083)$} & $0.018(0.014-0.022)$ & $0.064(0.058-0.070)$ & $1091(927-1404)$ \\
\hline & $22{ }^{\circ} \mathrm{C}$ post-exposed & $228(207-337)$ & \multicolumn{2}{|c|}{$0.083(0.070-0.093)$} & $0.029(0.014-0.043)$ & $0.060(0.054-0.075)$ & $363(299-631)$ \\
\hline
\end{tabular}



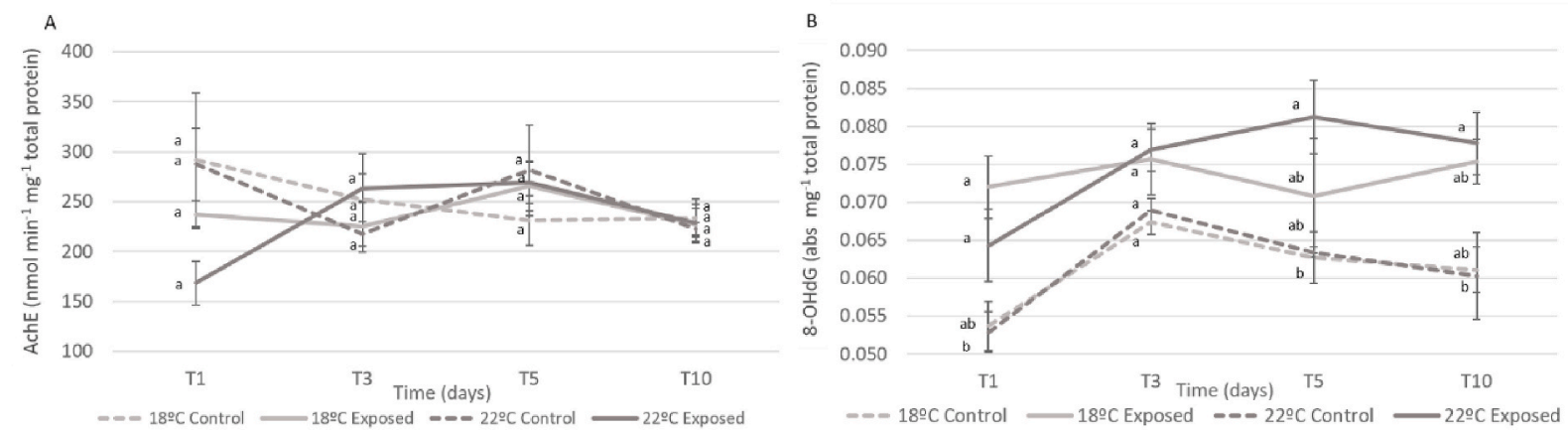

Fig. 4. A) Acetylcholinesterase activity (AChE, $\mathrm{nmol} \mathrm{min}^{-1} \mathrm{mg}^{-1}$ total protein) and B) DNA damage, determined via the quantification of 8-OHdG (abs mg ${ }^{-1} \mathrm{protein}^{-}$ of the control, La exposed and post-exposed glass eels' head at $18{ }^{\circ} \mathrm{C}$ and $22^{\circ} \mathrm{C}$ in the different sampling times (T1, T3, T5 and T10). Values represent medians $\pm \mathrm{SE}$. Different letters represent significant differences between treatments within each sampling time $(\mathrm{p}<0.05)$.

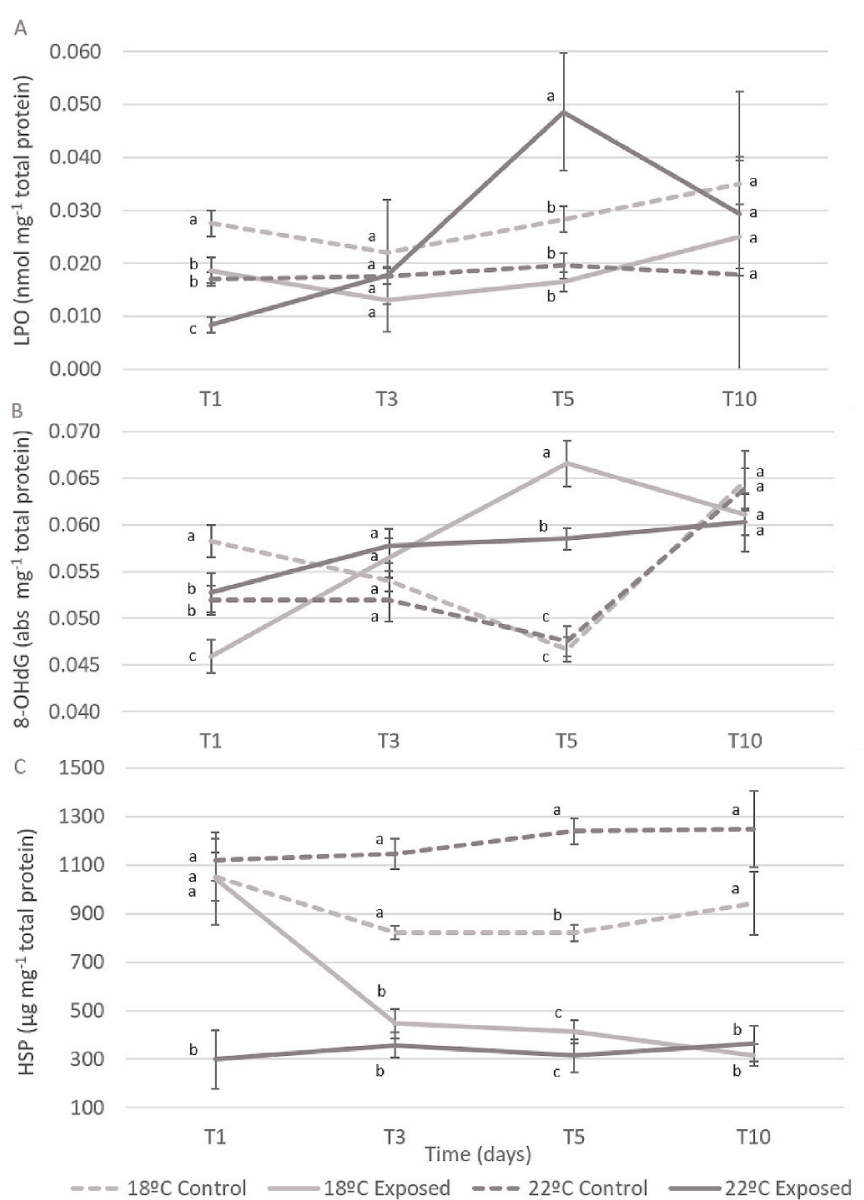

Fig. 5. A) Lipid peroxidation values (MDA concentrations, $\mathrm{nmol} \mathrm{mg}^{-1}$ total protein), B) DNA damage, determined via the quantification of 8-OHdG (abs $\mathrm{mg}^{-1}$ protein) and C) Heat Shock Protein $70\left(\mu \mathrm{g} \mathrm{mg}{ }^{-1}\right.$ protein) of the control, La exposed and post-exposed glass eels' body at $18^{\circ} \mathrm{C}$ and $22{ }^{\circ} \mathrm{C}$ in the different sampling times (T1, T3, T5 and T10). Values represent medians \pm SE. Different letters represent significant differences between treatments within each sampling time $(\mathrm{p}<0.05)$.

loads of contaminants into the environment and warming would play a major role on A. anguilla fitness and, ultimately, survival. Overall, our results showed that in a warming scenario accumulation and toxic effects of lanthanum are enhanced. To ensure that age-dependent differences of the organisms wouldn't influence the La accumulation, glass eels used in this study were in the same pigmentation stage to secure ontogeny similarity. Water $\mathrm{pH}$ and temperature are pointed has abiotic factors that influence La availability (Herrmann et al., 2016). Hence, $\mathrm{pH}$ was kept stable $(7.9 \pm 0.1)$ at a level known to have $90 \%$ of $\mathrm{La}$ as a trivalent ion (Bouyer et al., 2006) that can compete with $\mathrm{Ca}^{2+}$ for biological binding sites, and affect La toxicity (Barry and Meehan, 2000; Evans, 1983). Although water hardness can also influence this element availability (reviewed in Herrmann et al., 2016), it is not clear to comprehend how, and for that reason, the water hardness was kept as moderately hard $\left(105 \pm 5 \mathrm{mg} \mathrm{L}^{-1} \mathrm{CaCO}_{3}\right)$ throughout the experiment, for all four treatments, in order to avoid bias. Here we began to unveil the influence of temperature in the availability of La. At $18^{\circ} \mathrm{C}$ there was a $24.4 \%$ loss of La, after $24 \mathrm{~h}$ of exposure, either due to bioaccumulation, adsorption to particulate matter or glass tank walls. Interestingly, at 22 ${ }^{\circ} \mathrm{C}$ the loss was shortened to $18.3 \%$, after $24 \mathrm{~h}$ of exposure. Alterations in the partitioning between the sediments, water, atmosphere and biota of toxicants can be caused by climate change (Noyes et al., 2009). The increased temperature may interfere in air-surface exchange, deposition, and reaction rates (e.g. photolysis, biodegradation, oxidation in the air). The obtained results showed that in a warming scenario the bioavailability of La in water is slightly enhanced. The raised water temperature may as well alter contaminants to more bioactive metabolites, impairing homeostasis (reviewed in Noyes et al., 2009 and Manciocco et al., 2014).

In glass eels' heads, bioaccumulation increased consistently during the exposure period ( 5 days). At $18{ }^{\circ} \mathrm{C}$ post-exposed eels were able to eliminate La to values as the controls, however at a warming temperature $\left(22{ }^{\circ} \mathrm{C}\right)$ this elimination was not so effective. To the best of our knowledge, this is the first study addressing the combined effects of a climate change variable, specifically thermal stress, and La, therefore comparison with other data is arduous. Warmer temperatures often enhance fish metabolism (Anacleto et al., 2018) which can lead to higher contaminants' uptake, either due to increased ventilation or enhanced feeding rates (Maulvault et al., 2016). On another hand, warmer temperatures may also promote contaminants' metabolization and elimination (Serra-Compte et al., 2018). This is in line with our results, where in a warming condition, a higher accumulation was not accompanied by an enhanced elimination. The blood-brain barrier can limit the release of elements into the bloodstream, and thus affect elimination. Kiyatkin and Sharma (2009) described the permeability of this barrier as highly dependent on temperature by exposing rats to different temperatures. To preserve optimal neurotransmission and other vital functions, low elemental concentrations are usually found in the head (Mieiro et al., 2011). Interestingly, the skinless body of exposed glass eels presented globally lower accumulation values of La, than the head. Although this result is not in line with Figueiredo et al. (2018) presumably resulted from the higher (one order of magnitude) exposure concentration in the present experiment. At $18^{\circ} \mathrm{C}$, La concentrations in exposed glass eels' skinless body reached a peak at T3 and afterward the concentrations decreased steadily, even in a continuously exposed 
medium. This interesting and baffling pattern of elimination in a continuously exposed medium suggest the existence of an unknown mechanism in glass eels to cope with La contamination. As expected, bioaccumulation was greater at higher temperatures in the viscera and this body part presented, globally, the higher accumulation values. This body part was also able to eliminate La, at both $18{ }^{\circ} \mathrm{C}$ and $22{ }^{\circ} \mathrm{C}$, to non-exposed background values. This elimination ability was expected as, in fact, the viscera has been described as a primary accumulation and elimination organ in fish (e.g. Figueiredo et al., 2018; Pereira et al., 2015; Raimundo et al., 2013).

Aquatic communities can be resilient to environmental changes, such as thermal stress and increasing loads of pollutants (Snoeijs-Leijonmalm et al., 2017). However, these buffering capacities are limited and species can reach endpoints with permanent repercussions. The increased bio-activation or detoxification caused by warmer temperature will affect, accordingly, the toxicity of La. Acetylcholinesterase hydrolysis the neurotransmitter acetylcholine (Colovic et al., 2013) and when this process is impacted neurotransmission disturbance and stress occurs. In our previous study, we described a stimulatory AChE activity in exposed glass eels' heads, to $120 \mathrm{ng} \mathrm{L}^{-1}$ at $18{ }^{\circ} \mathrm{C}$. Interestingly, in the present study, glass eels' heads exposed to $1.5 \mu \mathrm{g} \mathrm{L}^{-1} \mathrm{La}$ (12,5-fold higher), did not show similar AChE activity. Agathokleous et al. (2018) and Zhang et al. (2017), amongst other authors, have described the hormesis effect of $\mathrm{La}$, in plants. Hormesis is a chemical phenomenon where stimulation can occur at low doses and inhibition can occur at high doses. Further dose-dependent effects of La have been demonstrated on the immune system of mammals. Foreman and Mongar (1973) also stated dose-dependent effects of La in mammals, high concentrations of La suppressed histamine secretion in the peritoneal cavity of rats, while low-dose promoted histamine release. As far as we are aware, the hormesis effect has not been described for fish, however, La could have triggered a hormesis response, not interfering with the AChE activity. On the other hand, DNA damage occurred in exposed glass eels' heads after 1 day at $18{ }^{\circ} \mathrm{C}$, being therefore caused by La exposure alone, and was exacerbated by warming. At $22^{\circ} \mathrm{C}$, La non-exposed eel's heads did not show DNA damage, dismissing the effect of temperature. The DNA damage values of the glass eels' head previously exposed to La, did not recover during the elimination phase (5 days), at both temperatures. This highlights the effects of La on the DNA, and the inability of eels to recover after being exposed to a La-contaminated environment. Overall, DNA damage values were greater in the head, than in the remaining body, which denotes the neurotoxic effects of La. The synergetic effect caused by warming and La accumulation on DNA, can be a result of ROS interaction with the DNA chain, which in turn can cause base oxidation, base-pair disparities and breaks, and ultimately trigger mutations with unknown consequences. This DNA damage can also be caused by protein damage, as damage in the proteasome is intrinsically related to genome repair mechanisms (Gueranger et al., 2014; Krisko and Radman, 2013).

Lipid peroxidation is caused by the reaction of ROS with lipids (Sachdeva et al., 2014). When lipid molecules are broken into LPO by-products such as malondialdehyde, lipid damage occurs. In exposed glass eels' body, LPO values reached a peak after 5 days of exposure to warming and La contamination. Since they occur in a chain of reaction manner, this peak suggests that the antioxidant enzymatic activity was insufficient to cope with both stressors, and was unable to avoid lipid damage. In fact, previous studies have described an increasing antioxidant enzymatic activity in fish that is still insufficient in avoiding lipid peroxidation (e.g. Pimentel et al., 2015), in a climate change scenario. This damage did not occur in the non-exposed glass eels' body under warming, nor at La exposed glass eels' body at $18^{\circ} \mathrm{C}$, suggesting that the effects of warming and La exposure on LPO are synergetic.

The heat shock response is a set of physiological mechanisms that aquatic organisms possess to evade deleterious effects caused by environmental stressors (Lesser, 2006). This response includes the synthesis of heat shock proteins that are vital in the stabilization and refolding of denatured protein (Tomanek, 2010). Increasing temperatures can lead to protein unfolding and thus interfere with their function (Dong et al., 2008). In this scenario HSP's are triggered. Our results revealed, as expected, the highest expressions of HSP in the non-exposed glass eel's body under warming. Remarkably, the expression of HSP was majorly suppressed in glass eels exposed to La. One day of exposure to La was insufficient to cause this inhibition at $18{ }^{\circ} \mathrm{C}$, nonetheless after T3 this suppression was evident. At $22^{\circ} \mathrm{C}$, where normally HSP's are triggered, one day of exposure to La was sufficient to repress these vital proteins. Wang et al. (2011) exposed hydroponically cultivated Vicia faba seedlings to different concentrations of $\mathrm{La}$, and described a hormetic dose-response, with HSP production enhanced at low doses and suppressed at higher doses. However, the lower dose in this paper $0.25 \mathrm{mg}$ $\mathrm{L}^{-1}$ ) is up to 150 times higher than the concentration used in this study $\left(1.5 \mu \mathrm{g} \mathrm{L}^{-1}\right)$, which could point to a species-specific reaction to La. Our results suggest that, when exposed to La, glass eels' will be unable to stabilize and refold denatured proteins, and prevent cellular damage, with a particular dramatic setup in a near-future scenario.

Dose responses are vital in toxicology and the assessment of the effects of La will depend on them. Furthermore, the influence of other water parameters, such as water hardness and major ions content, in the La availability and toxicity should also be considered. This is the first study to unveil the combined effects of warming and La and will set the baseline on which future studies dealing with this emergent problematic will build upon. Nevertheless, to better understand the effects of La in a changing world, the effects of global climate change (i.e. the combined effect of ocean acidification and warming) on REEs toxicity need to be scrutinized.

Concomitantly, the empirical data deriving from these studies will be pivotal for the decision-making process of policy makers (e.g. governments and environmental agencies) when legislating for these new emergent pollutants and timely environmental policies.

\section{Declaration of competing interest}

The authors declare that they have no known competing financial interests or personal relationships that could have appeared to influence the work reported in this paper.

\section{Acknowledgments}

Tiago F. Grilo acknowledges the Junior Researcher contract attributed by FCT (CEECIND/03517/2017). The authors would also like to acknowledge the strategic project UID/MAR/04292/2019 granted to MARE. Cátia Figueiredo also acknowledges the PhD grant SFRH/BD/ $130023 / 2017$ by FCT. The authors acknowledge all colleagues who provided technical and scientific insights. Finally, the authors thank the two anonymous reviewers for the useful comments and valuable advice for the improvement of this work.

\section{Appendix A. Supplementary data}

Supplementary data to this article can be found online at https://doi. org/10.1016/j.envres.2020.110051

\section{Credit author statement}

Cátia Figueiredo: Conceptualization, Methodology, Validation, Formal analysis, Investigation, Resources, Writing - original draft, Funding acquisition Joana Raimundo: Conceptualization, Validation, Resources, Writing - review \& editing, Funding acquisition, Ana Rita Lopes: Methodology, Validation, Investigation, Writing - review \& editing Clara Lopes: Validation, Investigation, Writing - review \& editing Nuno Rosa: Validation, Investigation Pedro Brito: Validation, Investigation, Writing - review \& editing Mário Diniz: Validation, Resources, Writing - review \& editing, Funding acquisition Miguel Caetano: Validation, Resources, Writing - review \& editing, Funding acquisition Tiago 
F. Grilo: Conceptualization, Methodology, Validation, Investigation, Resources, Writing - review \& editing, Supervision, Funding acquisition.

\section{Funding}

This work was supported by the MARE strategic project (UID/MAR/ 04292/2019) and Fundação para a Ciência e Tecnologia (FCT), through the project CLIMATOXEEL (PTDC/AAG-GLO/3795/2014) awarded to Tiago F. Grilo, the project REEUSE (PTDC/QEQ-EPR/1249/2014), the Junior Researcher contract attributed (CEECIND/03517/2017) awarded to Tiago F. Grilo and the PhD grant (SFRH/BD/130,023/2017) awarded to Cátia Figueiredo. The work was also supported by the Applied Molecular Biosciences Unit - UCIBIO (UIDB/04378/2020).

\section{Ethics}

Faculdade de Ciências da Universidade de Lisboa animal welfare organization (ORBEA, Statement 5/2016) and Direção-Geral de Alimentacão e Veterinária (DGAV) approved procedures in the context of the project CLIMATOXEEL (PTDC/AAG-GLO/3795/2014), fulfilling requirements imposed by the Directive 2010/63/EU of the European Parliament and of the Council of September 22, 2010 on the protection of animals used for scientific purposes.

\section{References}

Agathokleous, E., Kitao, M., Calabrese, E.J., 2018. The rare earth element (REE) lanthanum (La) induces hormesis in plants. Environ. Pollut. 238, 1044-1047.

Alexandrov, V.Y., 1969. Conformatonal flexibility of proteins, their resistance to proteinases and temperature conditions of life. Biosyst 3, 9-19.

Aljerf, L., 2016. Reduction of gas emission resulting from thermal ceramic manufacturing processes through development of industrial conditions. Sci. J. King Faisal Univ. 17, $1-10$.

Anacleto, P., Figueiredo, C., Baptista, M., Maulvault, A.L., Camacho, C., PousãoFerreira, P., Valente, L.M., Marques, A., Rosa, R., 2018. Fish energy budget under ocean warming and flame retardant exposure. Environ. Res. 164, 186-196.

Åström, M., 2001. Abundance and fractionation patterns of rare earth elements in streams affected by acid sulphate soils. Chem. Geol. 175, 249-258.

Barry, M.J., Meehan, B.J., 2000. The acute and chronic toxicity of lanthanum to Daphnia carinata. Chemosphere 41, 1669-1674.

Bouyer, F., Sanson, N., Destarac, M., Gerardin, C., 2006. Hydrophilic block copolymerdirected growth of lanthanum hydroxide nanoparticles. New J. Chem. 30, 399-408.

Borges, F.O., Santos, C.P., Sampaio, E., Figueiredo, C., Paula, J.R., Antunes, C., Rosa, R. Grilo, T.F., 2019. Ocean warming and acidification may challenge the riverward migration of glass eels. Biol. Lett. 15, 20180627.

Bradford, M.M., 1976. A rapid and sensitive method for the quantitation of microgram quantities of protein utilizing the principle of protein-dye binding. Anal. Biochem. $72,248-254$

Bukola, D., Zaid, A., Olalakan, E.I., Falilu, A., 2015. Consequences of anthropogenic activities on fish and the aquatic environment. Poult. Fish. Wild. Sci. 3, 138.

Cheng, K.C., Cahill, D.S., Kasai, H., Nishimura, S., Loeb, L.A., 1992. 8-Hydroxyguanine, an abundant form of oxidative DNA damage, causes G-T and A-C substitutions. J. Biol. Chem. 267, 166-172.

Cheung, W.W., Lam, V.W., Sarmiento, J.L., Kearney, K., Watson, R., Pauly, D., 2009. Projecting global marine biodiversity impacts under climate change scenarios. Fish Fish. 10, 235-251.

Colovic, M.B., Krstic, D.Z., Lazarevic-Pasti, T.D., Bondzic, A.M., Vasic, V.M., 2013. Acetylcholinesterase inhibitors: pharmacology and toxicology. Curr. Neuropharmacol. 11, 315-335.

Cooke, M.S., Evans, M.D., Dizdaroglu, M., Lunec, J., 2003. Oxidative DNA damage: mechanisms, mutation, and disease. Faseb. J. 17, 1195-1214.

Crook, V., Nakamura, M., 2013. Assessing supply chain and market impacts of a CITES listing on Anguilla species. Index 24 (i-iv 9), 24.

Cui, J.a., Zhang, Z., Bai, W., Zhang, L., He, X., Ma, Y., Liu, Y., Chai, Z., 2012. Effects of rare earth elements $\mathrm{La}$ and $\mathrm{Yb}$ on the morphological and functional development of zebrafish embryos. J. Environ. Sci. 24, 209-213.

Doney, S.C., Ruckelshaus, M., Duffy, J.E., Barry, J.P., Chan, F., English, C.A., Galindo, H. M., Grebmeier, J.M., Hollowed, A.B., Knowlton, N., Polovina, J., Rabalais, N.N., Sydeman, W.J., Talleu, L.D., 2011. Climate change impacts on marine ecosystems. Annu. Rev. Mar. Sci. 4, 11-37.

Dong, Y., Miller, L.P., Sanders, J.G., Somero, G.N., 2008. Heat-shock protein 70 (Hsp70) expression in four limpets of the genus Lottia: interspecific variation in constitutive and inducible synthesis correlates with in situ exposure to heat stress. Biol. Bull. 215, 173-181.

Drouineau, H., Durif, C., Castonguay, M., Mateo, M., Rochard, E., Verreault, G., Yokouchi, K., Lambert, P., 2018. Freshwater eels: a symbol of the effects of global change. Fish Fish. 19, 903-930.
Ellman, G.L., Courtney, K.D., Andres, V., Featherstone, R.M., 1961. A new and rapid colorimetric determination of acetylcholinesterase activity. Biochem. Pharmacol. 7, 88-95.

Evans, C.H., 1983. Interesting and useful biochemical properties of lanthanides. Trends Biochem. Sci. 8, 445-449.

Figueiredo, C., Grilo, T.F., Lopes, C., Brito, P., Diniz, M., Caetano, M., Rosa, R., Raimundo, J., 2018. Accumulation, elimination and neuro-oxidative damage under lanthanum exposure in glass eels (Anguilla anguilla). Chemosphere 206, 414-423.

Foreman, J.C., Mongar, J.L., 1973. The action of lanthanum and manganese on anaphylatic istamine secretion. Br. J. Pharmacol. 48, 527-537.

Grilo, T., Mendes, T., Coelho, J., Pereira, E., Pardal, M., Cardoso, P., 2015. Kinetics of mercury accumulation and elimination in edible glass eel (Anguilla anguilla) and potential health public risks. Water Air Soil Pollut. 226, 166.

Gueranger, Q., Li, F., Peacock, M., Larnicol-Fery, A., Brem, R., Macpherson, P., Egly, J.M., Karran, P., 2014. Protein oxidation and DNA repair inhibition by 6-thioguanine and UVA radiation. J. Invest. Dermatol. 134, 1408-1417.

Halliwell, B., Gutteridge, J.M., 2015. Free Radicals in Biology and Medicine. Oxford University Press, USA.

Herrmann, H., Nolde, J., Berger, S., Heise, S., 2016. Aquatic ecotoxicity of lanthanum-A review and an attempt to derive water and sediment quality criteria. Ecotoxicol. Environ. Saf. 124, 213-238.

IPCC, 2019. In: Pörtner, H.-O., Roberts, D.C., Masson-Delmotte, V., Zhai, P., Tignor, M., Poloczanska, E., Mintenbeck, K., Alegría, A., Nicolai, M., Okem, A., Petzold, J., Rama, B., Weyer, N.M. (Eds.), IPCC Special Report on the Ocean and Cryosphere in a Changing Climate (in press).

Kiyatkin, E.A., Sharma, H.S., 2009. Permeability of the blood-brain barrier depends on brain temperature. Neuroscience 161, 926-939.

Krisko, A., Radman, M., 2013. Phenotypic and genetic consequences of protein damage. PLoS Genet. 9, e1003801.

Kulaksız, S., Bau, M., 2011. Rare earth elements in the Rhine River, Germany: first case of anthropogenic lanthanum as a dissolved microcontaminant in the hydrosphere. Environ. Int. 37, 973-979.

Lecomte-Finiger, R., 1994. The early life of the European eel. Nature 370, 424-424.

Lesser, M.P., 2006. Oxidative stress in marine environments: biochemistry and physiological ecology. Annu. Rev. Physiol. 68, 253-278.

Lopes, A.R., Sampaio, E., Santos, C., Couto, A., Pegado, M.R., Diniz, M., Munday, P.L., Rummer, J.L., Rosa, R., 2018. Absence of cellular damage in tropical newly hatched sharks (Chiloscyllium plagiosum) under ocean acidification conditions. Cell Stress Chaperones 23, 837-846.

Lopes, A.R., Borges, F.O., Figueiredo, C., Sampaio, E., Diniz, M., Rosa, R., Grilo, T.F., 2019. Transgerational exposure to ocean acidification induces biochemical distress in a keystone amphipod species (Gammarus locusta). Environ. Res. 170, 168-177.

Lushchak, V.I., 2011. Environmentally induced oxidative stress in aquatic animals. Aquat. Toxicol. 101, 13-30.

Manciocco, A., Calamandrei, G., Alleva, E., 2014. Global warming and environmental contaminants in aquatic organisms: the need of the etho-toxicology approach. Chemosphere 100, 1-7.

Marques, A., Nunes, M.L., Moore, S.K., Strom, M.S., 2010. Climate change and seafood safety: human health implications. Food Res. Int. 43, 1766-1779.

Maulvault, A.L., Custódio, A., Anacleto, P., Repolho, T., Pousão, P., Nunes, M.L., Diniz, M., Rosa, R., Marques, A., 2016. Bioaccumulation and elimination of mercury in juvenile seabass (Dicentrarchus labrax) in a warmer environment. Environ. Res. 149, 77-85.

Mieiro, C.L., Pacheco, M., Pereira, M.E., Duarte, A.C., 2011. Mercury organotropism in feral European sea bass (Dicentrarchus labrax). Arch. Environ. Contam. Toxicol. 61, 135-143.

Moreira, A., Henriques, B., Leite, C., Libralato, G., Pereira, E., Freitas, R., 2020. Potential impacts of lanthanum and yttrium through embryotoxicity assays with Crassostrea gigas. Ecol. Indicat. 108, 105687.

Needhidasan, S., Melvin, S., Ramalingam, C., 2014. Electronic waste - an emerging threat to the environment of urban India. J. Environ. Health Sci. Eng. 12, 1-36.

Noyes, P.D., McElwee, M.K., Miller, H.D., Clark, B.W., Van Tiem, L.A., Walcott, K.C., Erwin, K.N., Levin, E.D., 2009. The toxicology of climate change: environmental contaminants in a warming world. Environ. Int. 35, 971-986.

Oliveira, M., Ahmad, I., Maria, V.L., Ferreira, C.S., Serafim, A., Bebianno, M.J., Pacheco, M., Santos, M.A., 2010. Evaluation of oxidative DNA lesions in plasma and nuclear abnormalities in erythrocytes of wild fish (Liza aurata) as an integrated approach for genotoxicity assessment. Mutat. Res. Genet. Toxicol. Environ. Mutagen 703, 83-89.

Pagano, G., Guida, M., Tommasi, F., Oral, R., 2015. Health effects and toxicity mechanisms of rare earth elements - knowledge gaps and research prospects. Ecotoxicol. Environ. Saf. 115, 40-48.

Pankhurst, N.W., Munday, P.L., 2011. Effects of climate change on fish reproduction and early life history stages. Mar. Freshw. Res. 62, 1015-1026.

Pereira, P., Raimundo, J., Barata, M., Araújo, O., Pousão-Ferreira, P., Canário, J., Almeida, A., Pacheco, M., 2015. A new page on the road book of inorganic mercury in fish body-tissue distribution and elimination following waterborne exposure and post-exposure periods. Metall 7, 525-535.

Pimentel, M.S., Faleiro, F., Diniz, M., Machado, J., Pousão-Ferreira, P., Peck, M.A., Pörtner, H.O., Rosa, R., 2015. Oxidative stress and digestive enzyme activity of flatfish larvae in a changing ocean. PloS One 10, e0134082.

Pinto, J., Costa, M., Leite, C., Borges, C., Coppola, F., Henriques, B., Monteiro, R., Russo, T., Di Cosmo, A., Soares, A.M., 2019. Ecotoxicological effects of lanthanum in Mytilus galloprovincialis: biochemical and histopathological impacts. Aquat. Toxicol. 211, 181-192. 
Pörtner, H.O., Peck, M., 2010. Climate change effects on fishes and fisheries: towards a cause-and-effect understanding. J. Fish. Biol. 77, 1745-1779.

Qinhai, H., 1996. Distribution and accumulation of lanthanum in Ctenopharyngodon ldellus. Agro-environmental Protection 15, 218-220.

Raimundo, J., Vale, C., Caetano, M., Giacomello, E., Anes, B., Menezes, G.M., 2013. Natural trace element enrichment in fishes from a volcanic and tectonically active region (Azores archipelago). Deep Sea Res. Pt II 98, 137-147.

Rattanaphra, D., Soodjit, P., Thanapimmetha, A., Saisriyoot Srinophakun, P., 2019. Synthesis, characterization and catalytic activity studies of lanthanum oxide from Thai monazite ore for biodiesel production. Renew. Energy 13, 1128-1137.

Sachdeva, M., Karan, M., Singh, T., Dhingra, S., 2014. Oxidants and antioxidants in complementary and alternative medicine: a review. Spatula DD 4, 1-16.

Sepúlveda, A., Schluep, M., Renaud, F.G., Streicher, M., Kuehr, R., Hagelüiken, C., Gerecke, A.C., 2010. A review of the environmental fate and effects of hazardous substances released from electrical and electronic equipments during recycling: examples from China and India. Environ. Impact Assess. Rev. 30, 28-41.

Serra-Compte, A., Maulvault, A.L., Camacho, C., Álvarez-Muñoz, D., Barceló, D., Rodríguez-Mozaz, S., Marques, A., 2018. Effects of water warming and acidification on bioconcentration, metabolization and depuration of pharmaceuticals and endocrine disrupting compounds in marine mussels (Mytilus galloprovincialis). Environ. Pollut. 236, 824-834.
Snoeijs-Leijonmalm, P., Schubert, H., Radziejewska, T., 2017. Biological Oceanography of the Baltic Sea. Springer Science \& Business Media.

Sørensen, J.G., Kristensen, T.N., Loeschcke, V., 2003. The evolutionary and ecological role of heat shock proteins. Ecol. Lett. 6, 1025-1037.

Tomanek, L., 2010. Variation in the heat shock response and its implication for predicting the effect of global climate change on species' biogeographical distribution ranges and metabolic costs. J. Exp. Biol. 213, 971-979.

Uchida, N., Matsukami, H., Someya, M., Tue, N.M., Viet, P.H., Takahashi, S., Tanabe, S., Suzuki, G., 2018. Hazardous metals emissions from e-waste-processing sites in a village in northern Vietnam. Emerg. Contam. 4, 11-21.

Uchiyama, M., Mihara, M., 1978. Determination of malonaldehyde precursor in tissues by thiobarbituric acid test. Anal. Biochem. 86, 271-278.

Wall, F., 2014. Rare earth elements. In: Gunn, A.G. (Ed.), Critical Metals Handbook. John Wiley \& Sons, pp. 312-339.

Wang, C., He, M., Shi, W., Wong, J., Cheng, T., Wang, X., Hu, L., Chen, F., 2011. Toxicological effects involved in risk assessment of rare earth lanthanum on roots of Vicia faba L. seedlings. J. Environ. Sci. 23, 1721-1728.

Zepf, V., 2013. Rare Earth Elements: what and where They Are, Rare Earth Elements. Springer, pp. 11-39.

Zhang, F., Cheng, M., Sun, Z., Wang, L., Zhou, Q., Huang, X., 2017. Combined acid rain and lanthanum pollution and its potential ecological risk for nitrogen assimilation in soybean seedling roots. Environ. Pollut. 231, 524-532. 